\title{
Genetic Variations and Relationships of Papua's Endemic Orchids Based on RAPD Markers
}

\author{
Barahima Abbas $^{1}$, Muhammad Dailami ${ }^{2}$, Florentina Heningtyas Listyorini' ${ }^{1}$ Munarti ${ }^{3}$ \\ ${ }^{1}$ Faculty of Agriculture, University of Papua (UNIPA), Manokwari, Indonesia; ${ }^{2}$ Faculty of Mathematics and Science, \\ University of Papua (UNIPA), Manokwari, Indonesia; ${ }^{3}$ Faculty of Teacher Training and Education Science, The \\ Pakuan University, Bogor, Indonesia
}

Correspondence to: Barahima Abbas, barahimabas@gmail.com

Keywords: Orchidaceae, Genetic Variation, Genetic Relationships, Papua's Endemic, RAPD

Received: September 29, $2017 \quad$ Accepted: November 14, $2017 \quad$ Published: November 17, 2017

Copyright $\odot 2017$ by authors and Scientific Research Publishing Inc.

This work is licensed under the Creative Commons Attribution-NonCommercial International License (CC BY-NC 4.0).

http://creativecommons.org/licenses/by-nc/4.0/

\section{(c) (1) \&) Open Access}

\section{ABSTRACT}

Orchidaceae has known as an attractive flower and immense species. We have found a large species of Orchidaceae grow naturally in Papua's jungle, Indonesia territorial. This study aims to reveal genetic variation and genetic relationships among endemic orchids in Papua based on RAPD markers. The study included 26 accessions of Papua's endemic orchids used for genomic DNA extraction. Genomic DNAs were extracted by using DNA extraction kit from Qiagen and genomic DNA amplification by using 10 decamer RAPD primers. DNA fragments that were amplified by Polymerase Change Reaction (PCR) were visualized and documented by using UV illumination apparatus. Genetically, endemic Orchids in Papua were described high variation. Fragments amplification by using ten RAPD primers and performed in the PCR tools resulted in 54 numbers of polymorphic fragments and no monomorphic band. The number of polymorphic bands per primer ranged from 4 to 7 with averaged 5.4 bands per assay unit. The genetic dissimilarities (GDs) among examined orchids ranged from 0.10 to 0.94 based on Nei's unbiased coefficients. Dendrogram construction showed that Papua's endemic orchid (PEO) samples different from another and separated to form group by their own at the 0.40 coefficient value and at the 0.6 coefficient value indicate that $\mathrm{PEO}$ sample is divided into nine groups i.e. samples at the genera level were separated into their own groups.

\section{INTRODUCTION}

The Orchidaceae is reported a huge species growing naturally and cultivated around the world, especially in the tropical countries. Orchidaceae was reported to consist of 35,000 species under 800 genera [1] 
and family of Orchidaceae between 25,000 and 30,000 different species around the world [2]. It has been reported that 5000 species of Orchidaceae existed in Indonesian and approximately a half of them (2770 species) existed in Papua islands, Indonesian territorial [3]. Several of those species which have attractive performance, either flower or vegetative growth were domesticated and cultivated as well as propagated by in vitro technique [4].

Papua and West Papua, Indonesia territorial have a unique and interesting variety of orchids, some of which are still found and grow wild in the forest and several species have been domesticated. Several species of Papua's orchid have been used as a parent for breeding program [5]. Orchid growing and developing in the world's wilderness are estimated there are 20,000 - 35,000 species [6] of 900 genera in the world and about 5000 species found in Indonesia [3, 5]. Estimated 2770 species are found in Papua and only 300 species have been identified according to the Chairman of the Indonesian Orchid Association (IOA) of Papua Province [7].

Information of plant genetic variation is very important for sustainable use, breeding program and germplasm conservation. A popular DNA markers used for revealing genetic differentiation and genetic relationships is Random Amplified Polymorphism DNA (RAPD) marker. The RAPD marker is one of many techniques used for molecular research. The advantages of RAPD markers are simpler in their preparation than other molecular markers. The other advantages of RAPD markers are easy to employ for examining the differentiation of organism [8-10], because it is not using radioactive and relative chief [8]. The RAPD analyses were reported to be used as marker for many aims of organism evaluation either alone or in tandem with another molecular marker, such as: genetic relationships among Brassica napus [11], genetic analyses of plant progenies [12], molecular characterization of reciprocal crosses of Orchidaceae [13], genetic variation in Vanillaplanifolia [14], molecular characterization and phylogenetic revealing of Orchidaceae [15], genetic linkage map [16], identification of grapevine [17], and genetic differentiation [18]. This study is carried out for revealing genetic diversity and genetic relationship among Papua's endemic orchids based on RAPD markers which would help for understanding of genetic profile that can be used to improve strategies for sustainable utilization, breeding program, and germplasm conservation in the future.

\section{MATERIALS AND METHODS}

\subsection{Plant Samples}

A total 26 accessions of endemic orchids were collected by local people from the jungle of Papua, Indonesia territorial. Phenotypic of Papua's endemic orchid (PEO) were used as plant materials in this study it sown in the Figure 1. The young leaf samples were preserved by using silica gel granules in zip lock plastic according to previous reported procedures [19]. The dried young leafs were grinded directly without using liquid nitrogen by using mortar and pestle until the tissue become fine powder. Isolation and extraction of genomic DNA from the dried leaf samples were performed by using procedures as described in Qiagen DNA extraction kit. The genomic DNA was achieved its keep in $-20^{\circ} \mathrm{C}$ in the freezer until ready to use.

\subsection{PCR Amplfication}

Ten decamer RAPD primers were employed in this research as follows: OPA1 (5'-CAGGCCC TTC-3'), OPA4 (5'-AATCGGGCTG-3'), OPA12 (5'-TCTGTGCTGG-3'), OPU3 (5'-CTATGCCGAC-3'), OPU8 (5'-GGCGAAGGTT-3'), OPAW-05 (5'-CTGCTTCGAG-3'), OPAE-16 (5'-TCCGTGCTGA-3'), OPD08 (5'-GTGTGCCCCA-3'), OPD11 (5'-AGCGCCATTG-3'), and OPU8 (5'-AGCGCCATTG-3'). The decamer random primers were provided original sequences by Operon Technologies, Alameda, USA and synthesized by Integrated DNA Technologies. The PCR reagents were mixed in a $25 \mu$ l volume containing $10 \mathrm{ng}$ genomic DNA, $2.0 \mu \mathrm{l}$ of $50 \mathrm{pM}$ primer, $2.5 \mu \mathrm{l}$ of $10 \times$ polymerase buffer, $2.5 \mu \mathrm{l}$ of $2.5 \mathrm{mM}$ dNTPs, 1.0 $\mathrm{U}$ AmpliTaq Gold, $2.0 \mu \mathrm{l}$ of $3 \mathrm{mM} \mathrm{MgCl}$, and Milli Q Water. 


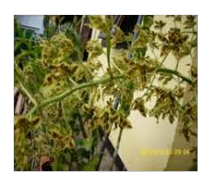

Ac01

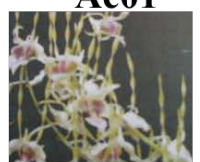

Ac08

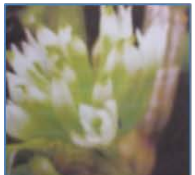

Ac15

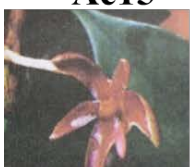

Ac22

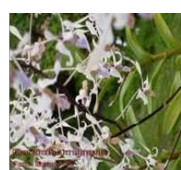

Ac02

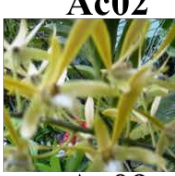

Ac09

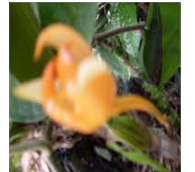

Ac16

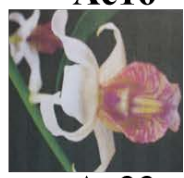

Ac23

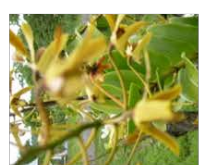

Ac03

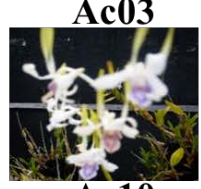

Ac10

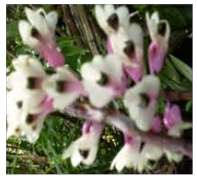

Ac17

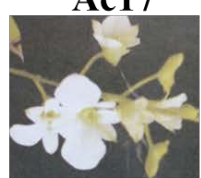

Ac24

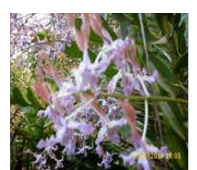

Ac04

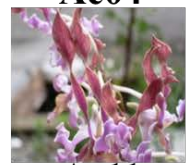

Ac11

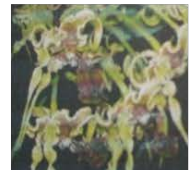

Ac18

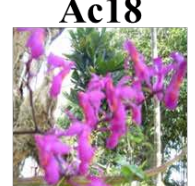

Ac25

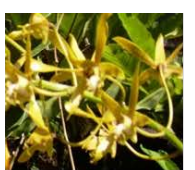

Ac05

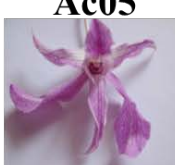

Ac12

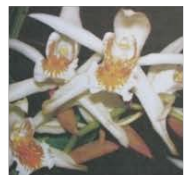

Ac19

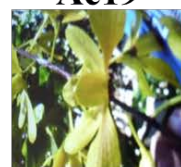

Ac26

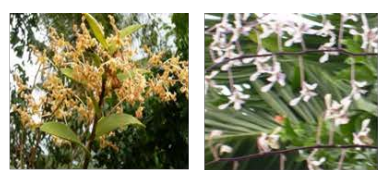

Ac06

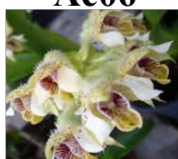

Ac07

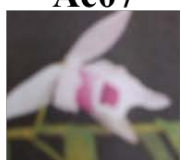

Ac13

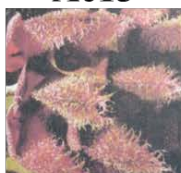

Ac20

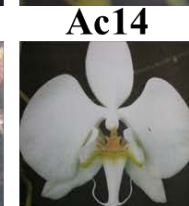

Ac21

Figure 1. Flower performances of PEO used in the study. Grammatophyllum scriptum (Ac01). Dendrobium lineale type 1 (Ac02), Dendrobium sp1 (Ac03). Dendrobium gouldii (Ac04), Dendrobium mirbelianum type 1 (Ac05), Dendrobium discolor (Ac06), Dendrobium lineale type 2 (Ac07), Dendrobium antenatum type 1 (Ac08), Dendrobium mirbelianum type 2 (Ac09), Dendrobium antenatum (Ac10), Dendrobium aries (Ac11), Dendrobium sp2 (Ac12), Dendrobium macrophyllum (Ac13), Dendrobium anosnum (Ac14), Dendrobium capituliflorum (Ac15), Dendrobium digibum (Ac16), Dendrobium simillieae (Ac17), Dendrobiums spectabile (Ac18), Collagen asperata (Ac19), Bulbophylum phalaenopsis (Ac20), Phalaenopsis amibilis (Ac21), Bulbophylum patens (Ac22), Dendrobium nindii (Ac23), Dendrobium affine (Ac24), Ascoglossum calepsum (Ac25), and Dendrobium sculery(Ac26).

Amplification was performed in a programmable Thermal Cycler (Takara) for an initial denaturation at $94^{\circ} \mathrm{C}$ for $2 \mathrm{~min}, 40$ cycles denaturation at 94 for $1 \mathrm{~min}$, annealing at $37^{\circ} \mathrm{C}$, extension at $72^{\circ} \mathrm{C}$ for $2 \mathrm{~min}$, final extension at $72^{\circ} \mathrm{C}$ for $5 \mathrm{~min}$, and holding at $4^{\circ} \mathrm{C}$. The Amplified DNA fragments were resolved in $2.0 \%$ agarose gel, electrophoresis at $100 \mathrm{~V}$ using $1 \times$ TAE buffer, standard molecular weight marker using a $100 \mathrm{bp}$ DNA ladder (Takara), staining with Ethidium bromide $(1 \mu \mathrm{l} / \mathrm{l})$ for $30 \mathrm{~min}$, visualization and documentation by using UV illuminator equipment and digital camera. The PCR reaction was repeated more than one times per sample for each primer to ensure the reproducibility of the amplified bands. Faint bands were not considered for scoring and calculation.

\subsection{Data Analysis}

RAPD fragments were scored as present (1) and absent (0). The scorer band in the formed of a binary data were analyzed the genetic variation, and genetic relationships among Papua's endemic orchids. The dissimilarity matrix was calculated by using distance coefficient. The dissimilarity was employed for clustering of the Papua's endemic orchids by the Unweighted Pair-Group Method Arithmetic Average (UPGMA), using the Sequential Agglomerative Hierarchical Nested Cluster Analysis (SAHN-clustering) [20] and TREE program from NTSYS-pc, version 2.02 packages [21]. Bootstrap analysis by 1000 permutation times were performed by using software Tools for Genetic Analysis (TFPGA 1.3); [22]. The average polymorphic information contents (PIC) of RAPD primers were calculated by using [23] formula $\left(\mathrm{PIC}_{\mathrm{i}}=\right.$ $1-\sum p I^{2}$, pi is the frequency of the $i$ bands). 


\section{RESULTS AND DISCUSSIONS}

\subsection{Polymorphism of RAPD Markers}

Amplification fragments by using ten RAPD primers and performed in the PCR tools were resulted 54 numbers of polymorphic fragments and no monomorphic band. The number of polymorphic bands per primer ranged from 4 (OPU8) to 7 (OPU3) with averaged 5.4 bands per assay unit. The number of polymorphic band that were observed in this work is lower than the number of bands were reported in the species of Phalaenopsis [15] and in the genus of Catasetum [24]. The fragment size range among 100 and $1400 \mathrm{bp}$, and the number of genotypes range from 9 (OPA12) to 17 (OPAW-05) with average 13.5 genotypes (Table 1).

The PIC value was performed to estimate the power of discriminatory the markers. A large proportion of PIC value has a high discrimination power. The PIC values were calculated range from 0.71 to 0.92 . In the previous studies were reported that the PIC of within species of Phalaenopsis reached 0.99 [15]. Primer OPA1 and OPD11 have the highest PIC value (0.92), therefore both these primers have the highest discrimination power comparing overall primer used in this research. Otherwise, the lowest PIC value was observed at primer OPA12 with 0.71 PIC values (Table 1). An example of amplification pattern for molecular characterization generated by RAPD markers is shown in Figure 2.

Table 1. Amplification results of 10-mer RAPD primers used for discrimination of 26 samples Papu's endemic orchid.

\begin{tabular}{cccccc}
\hline Primer name & Primer Sequences $\left(5^{\prime}-3^{\prime}\right)$ & $\begin{array}{c}\text { Number of polymorphic } \\
\text { fragments }\end{array}$ & $\begin{array}{c}\text { Fragment size } \\
\text { range (bp) }\end{array}$ & $\begin{array}{c}\text { Number of } \\
\text { genotypes }\end{array}$ & PIC \\
\hline OPA1 & CAGGCCCTTC & 6 & $100-1000$ & 15 & 0.92 \\
OPA4 & AATCGGGCTG & 6 & $150-1300$ & 15 & 0.90 \\
OPA12 & TCTGTGCTGG & 4 & $250-1100$ & 09 & 0.71 \\
OPU3 & CTATGCCGAC & 7 & $150-1000$ & 14 & 0.90 \\
OPU8 & GGCGAAGGTT & 5 & $150-1000$ & 12 & 0.90 \\
OPAW-05 & CTGCTTCGAG & 6 & $150-1100$ & 17 & 0.91 \\
OPAE-16 & TCCGTGCTGA & 5 & $200-1400$ & 14 & 0.90 \\
OPD08 & GTGTGCCCCA & 6 & $200-800$ & 11 & 0.83 \\
OPD11 & AGCGCCATTG & 5 & $200-700$ & 16 & 0.92 \\
OPU8 & AGCGCCATTG & 4 & $150-1300$ & 12 & 0.86 \\
\hline
\end{tabular}

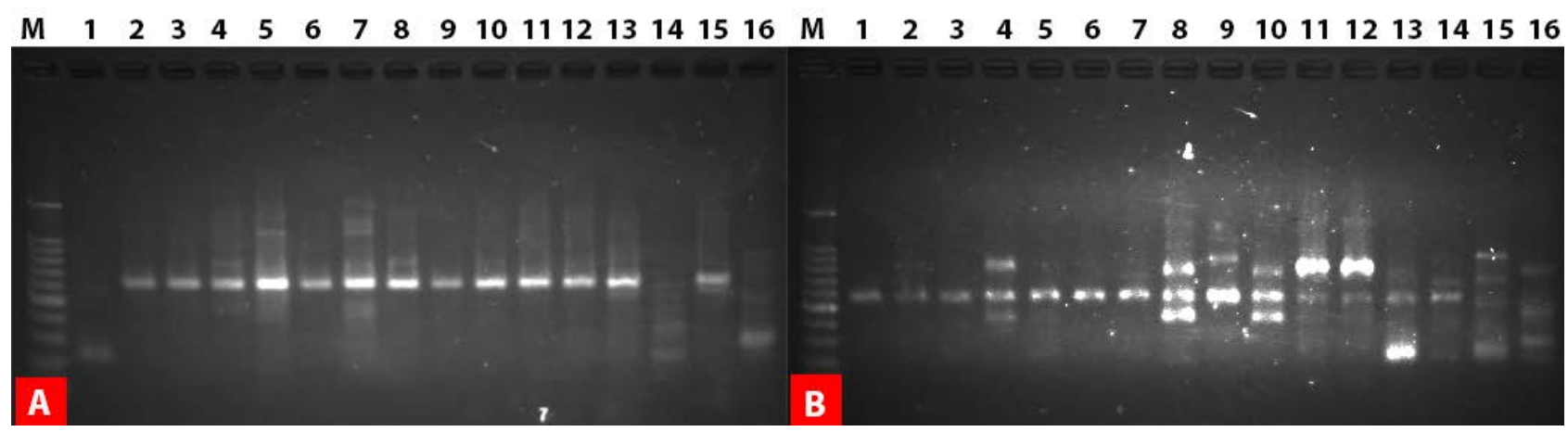

Figure 2. Performance of RAPD fragment by using OPA12 (A) and OPAE-16 (B) on 2.0\% agarose gel. Marker (M) and the number of well indicated number of orchid samples. 


\subsection{Genetic Variations}

The genetic dissimilarities (GDs) among examined orchids were range 0.10 to 0.94 based on [25] unbiased coefficients. The highest GDs values were found between $A$. calepsum (Ac25) and $P$. amibilis (Ac21) with $0.94 \mathrm{GDs}$ value then followed by pairwise differences of $A$. Calepsum and $C$. asperata with 0.90 GDs value and the smallest GDs values among genera were found between $D$. aries (Ac11) and $A$. Calepsum (Ac25) with 0.23 GDs value (Table 2). Genetic distances of PEO were found in this study, it showed a

Table 2. Genetic distances of 26 PEO based on fragment amplified of 10 RAPD primers used and calculated by using Nei's unbiased distance.

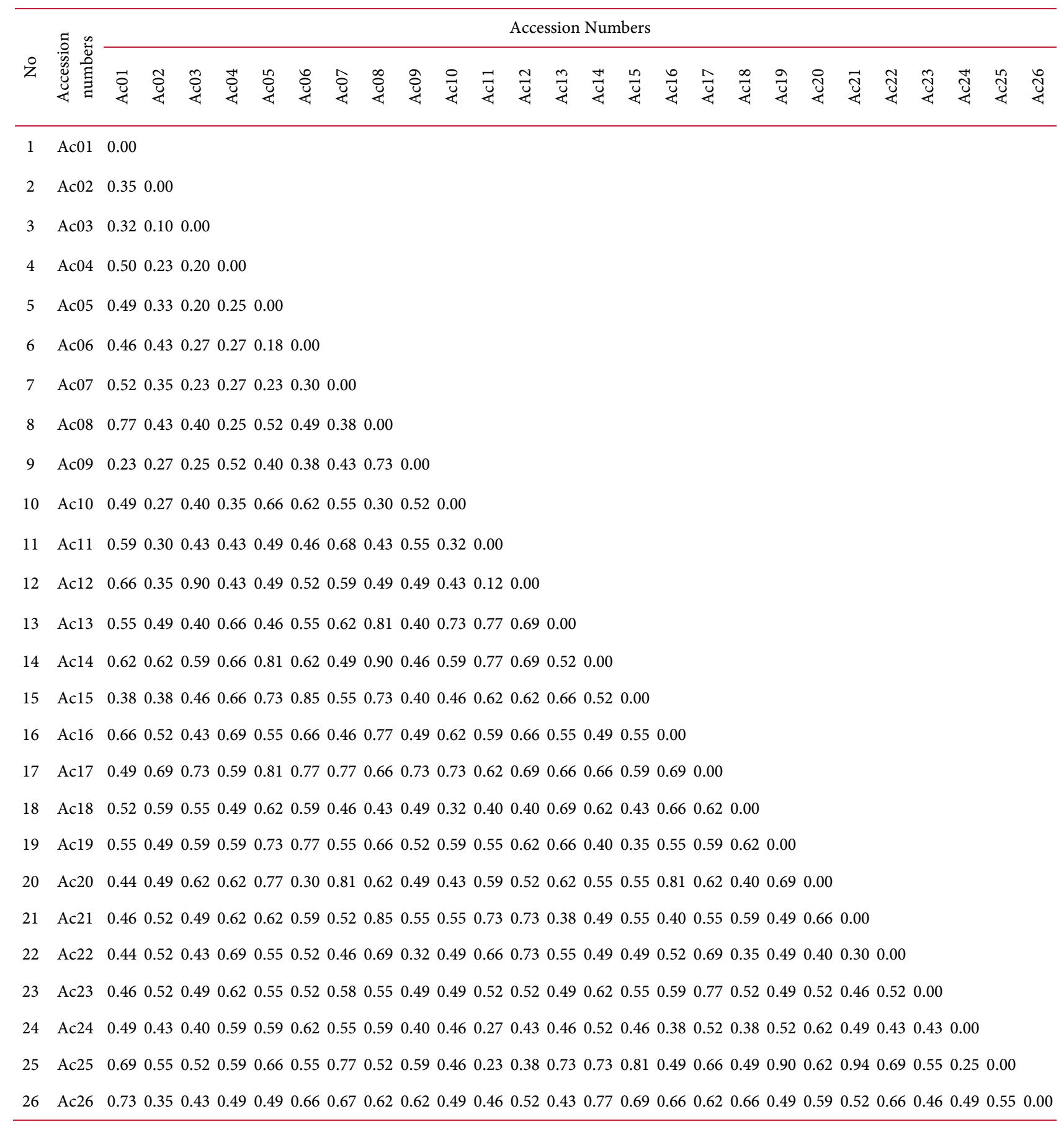


wide range of genetic distances. In the previous studies were reported that the genetic variation of orchid species also shows high variation [26-28]. The range of high genetic distance values based on the results of Nei's unbiased distance analysis is reflected from the highly variable phenotype of orchid flowers (Figure 2).

The GDs among species of Dendrobium were range 0.10 to 0.90 based on Nei's unbiased coefficient. The highest GDs values were found between D. Stratiotes (Ac08) and D. anosnum (Ac14) with 0.90 GDs value then followed by pairwise differences of D. Stratiotes (Ac08) and Dendrobium sp3 with 0.77 GDs value and the smallest GDs value were found between D. Lineale type1 (2) and Dendrobium sp1 (Ac03) with 0.10 GDs value. The calculation results of genetic variation among orchid species in this investigation resemble those of Cajanus cajan, Cajanus albicans, and Cajanus liniatus which have a wide range of genetic differences based on RAPD markers [29].

\subsection{Genetic Relationships}

Dendrogram construction of PEOs is based on 54 polymorphic fragments of 10 RAPD primers as markers by using UPGMA method of Nei's unbiased distance [24]. Dendrogram construction showed that PEO samples different from another and separated to form group by their self at the 0.40 coefficient value. This phenomenon correlated with different morphological phenotypes of flower. In the previous studies were reported that a lot of species of plant showed us their phenotypic traits correlated with molecular assessment [30-33]. Conformities of morphological traits and genetic characteristics by using molecular marker were reported also at sago palm species $[34,35]$. At the 0.6 coefficient value indicates that PEO sample is divided into nine groups (Figure 3) i.e. each sample at the genera level was separated into their own groups. Group 1 consists of two individuals namely Ascoglossum calepsum and Dendrobium sp2; Group 2 consists of four individuals namely Bulbophylum phalaenopsis, Dendrobium anosnum, Dendrobium Aaries, and Dendrobium digibum; Group 3 consists of seven individuals namely Dendrobium nindii, Dendrobium capituliflorum, Bulbophylum patens, Dendrobium mirbelianum type 2, Dendrobium antenatum type 1, Dendrobiums spectabile, and Dendrobium mirbelianum type 1; Group 4 consist Collagen asperata only; Group 5 consist Dendrobium simillieae only; Group 6 consists of two individuals

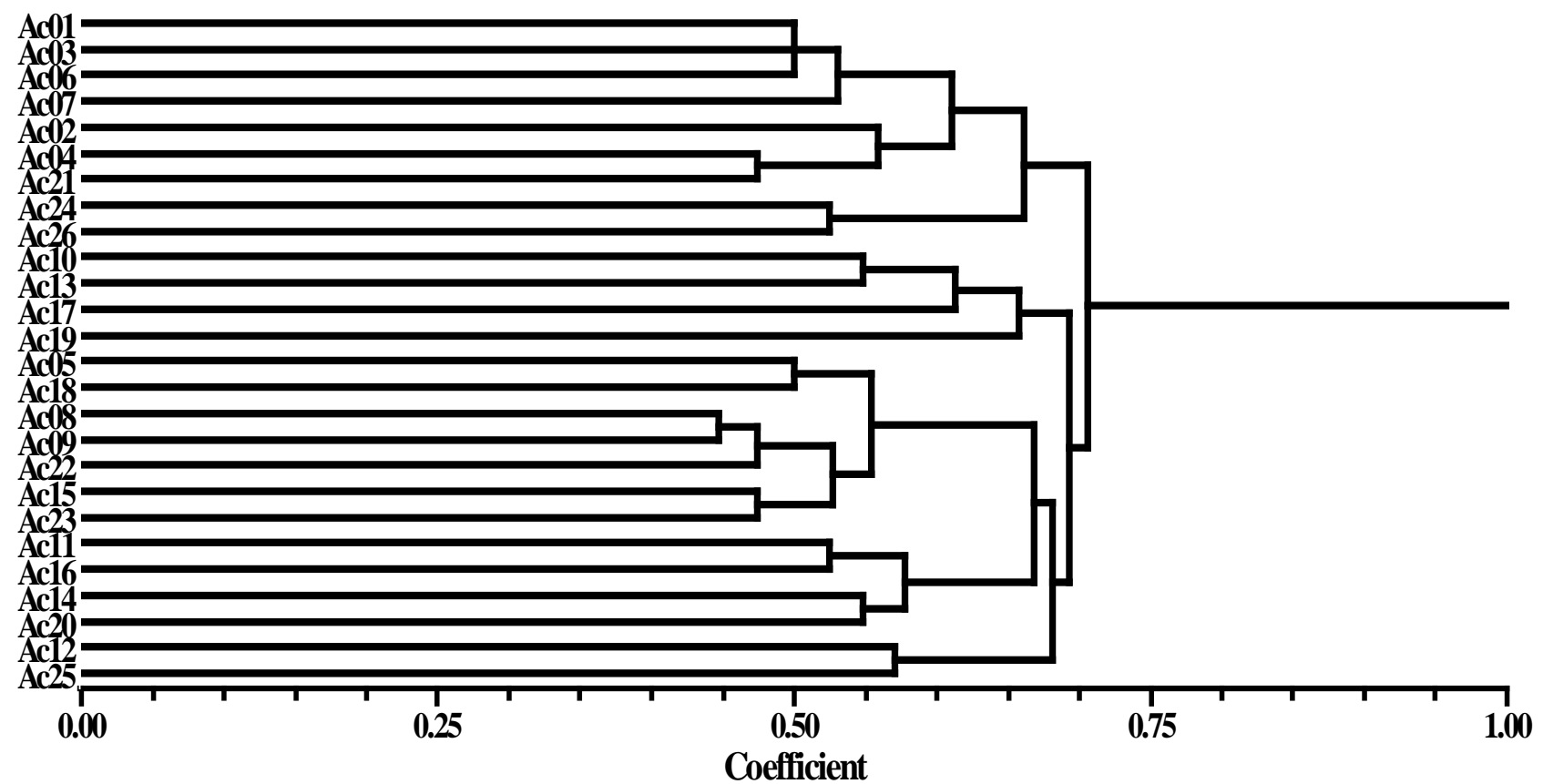

Figure 3. Dendrogram construction based on UPGMA methods by using Nei's unbiased distance of 26 accessions of PEO and determined by 54 polymorphic fragments of 10 RAPD primers as marker. 
namely Dendrobium antenatum and Dendrobium macrophyllum; Group 7 consists of Dendrobium affine and Dendrobium sculery, Group 8 consists of Dendrobium lineale type 2, Dendrobium gouldii, and Phalaenopsis amibilis; and Group 9 consists of Grammatophyllum scriptum, Dendrobium sp1, Dendrobium discolor, and Dendrobium lineale type 1.

\section{CONCLUSION}

Genetically, endemic Orchids in Papua were described high variation. Amplification fragments by using ten RAPD primers and performed in the PCR tools resulted in 54 numbers of polymorphic fragments and no monomorphic band. The number of polymorphic bands per primer ranged from 4 to 7 with an averaged 5.4 bands per assay unit. The genetic dissimilarities (GDs) among examined orchids ranged from 0.10 to 0.94 based on Nei's unbiased coefficients. Dendrogram construction showed that Papua's endemic orchid (PEO) samples different from another and separated to form group by their own at the 0.40 coefficient value and at the 0.6 coefficient value indicate that $\mathrm{PEO}$ sample is divided into nine groups i.e. each sample at the genera level was separated into their own groups. All samples of PEO used in the study are advised to be conserved prior to extinction.

\section{ACKNOWLEDGEMENTS}

Grateful thanks go to Directorate General of Higher Education (DGHE) of Indonesia for providing financial support with Stranas Research Skim. Thanks also to all who were contributed and reviewed in this work.

\section{REFERENCES}

1. Singh, M.K., Sherpa, A.R, Hallan, V. and Zaidi, A.A. (2007) A Potyvirus in Cymbidium spp. in Northern India. Australasian Plant Disease Notes, 2, 11-13. https://doi.org/10.1071/DN07005

2. Meisel, J.E., Kaufmann, R.S. and Pupulin, F. (2014) Orchids of Tropical America: An Introduction and Guide. Cornell University Press, Ithaca and London, 259 p. https://books.google.co.id/books?isbn=0801454921

3. Sutiyoso and Sarwono (2004) Orchids Care. Penebar Swadaya, Jakarta. (in Indonesian)

4. Abbas, B., Listyorini, F.H. and Amriati, B (2011) In vitro Seeds Germination and Plantlets Development of Grammatophyllum scriptum Lindl. (Orchidaceae). African Journal of Plant Science, 2, 154-159.

5. Sapto, H.P. (2009) The Diversity of Orchid Archipelago and the Lack of Taxonomist. (Accessed 5/2'2010) (in Indonesian)

6. Simardjo, M. (2009) Dewndrobium Species from Papua Have Been Used as a Parent for Breeding Activity (Indomesia Language). Proceeding Efforts to Develop and Preserve the Natural Orchid of West Papua.

7. World Wildlife Fund (WWF) (2007) Bunga Rampai ALAMKU-Bird's Head Seascape. 202 p. http://birdsheadseascape.com/download/research/social\%20Science\%20and\%20development/Bunga\%20Rampai \%20ALAMKU\%202007.pdf

8. Powel, W., Castillo, C.O., Chaluers, K.J., Provan, J. and Waugh, R. (1995) Polymerase Chain Reaction Based-Assays for the Characterization of Plant Genetic Resources. Electrophoresis, 16, 1726-1730. https://doi.org/10.1002/elps.11501601285

9. Colombo, C., Second, G., Valle, T.L. and Charrier, A. (1998) Genetic Diversity Characterization of Cassava Cultivars (Manihot esculenta Cranz.) RAPD Markers. Genetics and Molecular Biology, 21, 69-84. https://doi.org/10.1590/S1415-47571998000100018

10. Ferdinandez, Y.S.N., Somers, D.J. and Coulman, B.E. (2001) Estimation the Genetic Relationship of Hybrid Bromegrass to Smooth Bromegrass and Medow Bromegrass Using RAPD Markers. Plant Breeding, 120, 149-153. https://doi.org/10.1046/j.1439-0523.2001.00555.x 
11. Cartea, M.E., Soengas, P., Picoaga, A. and Orda's, A. (2005) Relationships among Brassica napus (L.) Germplasm from Spain and Great Britain as Determined by RAPD Markers. Genetic Resources and Crop Evolution, 52, 655-662. https://doi.org/10.1007/s10722-003-6014-8

12. Venkatachalam, L., Sreedhar, R.V. and Bhagyalakshmi, N. (2007) Genetic Analyses of Micropropagated and Regenerated Plantlets of Banana as Assessed by RAPD and ISSR Markers. In Vitro Cellular \& Developmental Biology, 43, 267-274.

13. Kishor, R., Devi, H.S. and Jeyaram, K. (2008) Molecular Characterization of Reciprocal Crosses of Aeridesvandarum and Vanda stageana (Orchidaceae) at the Protocorm Stage. Plant Biotechnology Reports, 2, 145-152. https://doi.org/10.1007/s11816-008-0053-8

14. Minoo, D., Jayakumar, V.N., Veena, S.S., Vimala, J., Basha, A. and Saji, K.V. (2008) Genetic Variations and Interrelationships in Vanillaplanifolia and Few Related Species as Expressed by RAPD Polymorphism. Genetic Resources and Crop Evolution, 55, 459-470. https://doi.org/10.1007/s10722-007-9252-3

15. Niknejad, A., Kadir, M.A., Kadzimin, S.B., Abdullah, N.A.P. and Sorkheh, K. (2009) Molecular Characterization and Phylogenetic Relationships among and within Species of Phalaenopsis (Epindenroideae: Orchidaceae) Based on RAPD Analyses. African Journal of Biotechnology, 8, 5225-5240.

16. Pfender, W.F., Saha, M.C., Johnson, E.A. and Slabaugh, M.B. (2011) Mapping with RAD (Restriction-Site Associated DNA) Markersto Rapidly Identify QTL for Stem Rust Resistance in Loliumperenne. Theoretical and Applied Genetics, 122, 1467-1480. https://doi.org/10.1007/s00122-011-1546-3

17. Zhao, M.Z., Zhang, Y.P., Wu, W.M., Wang, C., Qian, Y.M., Yang, G. and Fang, J.G. (2011) A New Strategy for Complete Identification of 69 Grapevine Cultivars using Random Amplified Polymorphic DNA (RAPD) Markers. African Journal of Plant Science, 5, 273-280.

18. Arias, A., Moreno, M.F., Tajes, J.F., Gaspar, M.B. and Jméndez, J.W. (2011) Strong Genetic Differentiation among East Atlantic Populations of the Sword Razor Shell (Ensissiliqua) Assessed with mtDNA and RAPD Markers. Helgoland Marine Research, 65, 81-89. https://doi.org/10.1007/s10152-010-0203-6

19. Chase, M. and Hill, H. (1991) Silica Gel: An Ideal Material for Field Preservation of Leaf Samples. Taxon, 40, 215-220. https://doi.org/10.2307/1222975

20. Sneath, P.H. and Sokal, R.R. (1973) Numerical Taxonomy. Freeman, San Francisco, 573 p.

21. Rohlf, F.J. (1998) NTSYS-pc Numerical Taxonomy and Multivariate Analysis System. Version 2.02, Exter Sift Ware, New York.

22. Miller, M.P. (1997) Tools for Population Genetic Analyses (TFPGA) Version 1.3. Departement of Biological Sciences-Box 5640, Northern Arizona University.

23. Powel, W., Morgante, M., andre, C., Hanafey, M., Vogel, J., Tingey, S. and Rafalski, A. (1996) The Comparison of RFLP, RAPD, AFLP, and SSR (Microsatellite) Markers for Germplasm Analysis. Molecular Breeding, 2, 225-238. https://doi.org/10.1007/BF00564200

24. Oliveira, L.V.R., Faria, R.T., Ruas, C.F., Ruas, P.M., Santos, M.O. and Cavarlho, V.P. (2010) Genetic Analysis of Species in the Genus Catasetum (Orchidaceae) using RAPD Markers. Brazilian Archives of Biology and Technology, 53, 375-387. https://doi.org/10.1590/S1516-89132010000200017

25. Nei, M. (1978) Estimation of Average Heterozigosity and Genetic Distance from Small Number of Individuals. Genetics, 89, 583-590.

26. Ding, G., Zhang, D., Ding, X., Zhou, Q., Zhang, W. and Li, X. (2008) Genetic Variation and Conservation of the Endangered Chinese Endemic Herb Dendrobium officinale Based on SRAP Analysis. Plant Systematics and Evolution, 276, 149-156. https://doi.org/10.1007/s00606-008-0068-1

27. Forrest, A.D., Hollingsworth, M.L., Hollingsworth, P.M., Sydes, C. and Bateman, R.M. (2004) Population Ge- 
netic Structure in European Populations of Spiranthes romanzoffiana Set in the Context of Other Genetic Studies on Orchids. Heredity, 92, 218-227. https://doi.org/10.1038/sj.hdy.6800399

28. Aceto, S., Caputo, P., Cozzolino, S., Gaudio, L. and Moretti, A. (1999) Phylogeny and Evolution of Orchis and Allied Genera Based on ITS DNA Variation: Morphological Gaps and Molecular Continuity. Molecular Phylogenetics and Evolution, 13, 67-76. https://doi.org/10.1006/mpev.1999.0628

29. Yadav, K., Yadav, S.K., Yadav, A., Pandey, V.P. and Dwivedi, U.N. (2012) Genetic Diversity of Pigeonpea (Cajanus cajan L. Millsp. Culviras and Its Wild Relatives using Randomly Amplified Polymorphic DNA (RAPD) Markers. American Journal of Plant Science, 3, 322-330. https://doi.org/10.4236/ajps.2012.33038

30. Waitt, D.E. and Levin, D.A. (1998) Genetic and Phenotypic Correlations in Plants: A Botanical Test of Cheverud's Conjecture. Heredity, 80, 310-319. https://doi.org/10.1046/j.1365-2540.1998.00298.x

31. Moniruzzaman, M., Zaman, M.A., Hossain, M.E., Bhuiyan, M.M.H. and Rahman, M.Z. (2012) Genetic Variability and Character Associated in Some Native Orchid Species (Dendrobium spp.). The Agriculturist, 10, 1-9.

32. Wahba, L.E., Hazlina, N., Fadelah, A. and Ratnam, W. (2014) Genetic Relatedness among Dendrobium (Orchidaceae) Species and Hybrids using Morphological and AFLP Markers. Hort Science, 49, 524-530.

33. Giri, L., Jugran, A.K., Bahukhandi, A., Dhyani, P., Bhatt, I.D., Rawal, R.S., Nandi, S.K. and Dhar, U. (2017) Population Genetic Structure an d Marker Trait Associations using Morphological, Phytochemical and Molecular Parameters in Habenaria edgeworthii-A Threatened Medicinal Orchid of West Himalaya, India. Applied Biochemistry and Biotechnology, 181, 267-282. https://doi.org/10.1007/s12010-016-2211-8

34. Abbas, B., Renwarin, Y., Bintoro, M.H., Sudarsono, S., Surahman, M. and Ehara, H. (2010) Genetic Diversity of Sago Palm in Indonesia Based on Chloroplast DNA (cpDNA) Markers. Journal of Biological Diversity, 11, 112-117. https://doi.org/10.13057/biodiv/d110302

35. Abbas, B. and Ehara, H. (2012) Assessment Genetic Variation and Relationship of Sago Palm (Metroxylon sagu Rottb.) in Indonesia Based on Specific Expression Gene (Wx Genes) Markers. African Journal of Plant Science, 6, 314-320. 